\title{
EFFECT OF COMBINATION SOY BEAN OIL AND OLEIC ACID TO CHARACTERISTIC, PENETRATION, PHYSICAL STABILITY OF NANOSTRUCTURE LIPID CARRIER RESVERATROL
}

\author{
Widji Soeratri, Rohmawati Hidayah, Noorma Rosita \\ Department of Pharmaceutical, Faculty of Pharmacy, Universitas Airlangga, Surabaya, Indonesia
}

\section{ABSTRACT}

Resveratrol is an antioxidant that can be used as anti-aging. Topical use has several problems because solubility in water is low and unstable to light. This study aimed to evaluate the effect of the combination of soy bean oil and oleic acid liquid lipids on the characteristics, penetration, and stability of resveratrol nanostructured lipid carriers (NLC). Nanostructured lipid carriers (NLC) were made with high shear homogeneous technique. To determine the characterization of NLC, diffraction scanning calorimetry, Xray diffraction, and Fourier transforms infrared spectrophotometry were used. Examination of the morphological form was carried out with a transmission electron microscope. The particle size and polydispersity index examination were measured by the Delsa Nano ${ }^{\mathrm{TM}}$ particle size analyzer, while the efficiency of trapping resveratrol in the NLC system was measured by the dialysis membrane method. Furthermore, the penetration depth test on the skin of mice was done by fluorescence microscope method using rhodamine $B$ markers. Physical stability test was performed by examination of particle size and index polydispersity for 30 days. The formula with liquid soy bean oil and oleic acid liquid lipids improved the characteristics including the effectiveness of entrapment and colloidal stability. However, the formula with soy bean oil and oleic acid combination liquid lipids did not provide better penetration into the skin than the use of single liquid lipids. While the formula with soy bean oil and oleic acid liquid lipids proved to improve the physical stability for 30 days.

Keywords: Nanostructured lipid carriers; resveratrol; soy bean oil; oleic acid; cetyl palmitat; high pressure homogenization; physicochemical properties; skin penetration

\section{ABSTRAK}

Resveratrol adalah antioksidan yang dapat digunakan sebagai anti penuaan. Penggunaan topikal memiliki beberapa masalah karena kelarutan dalam air rendah dan tidak stabil terhadap cahaya. Penelitian ini bertujuan untuk mengevaluasi pengaruh kombinasi minyak kacang kedelai dan cairan lipid asam oleat terhadap karakteristik, penetrasi, dan stabilitas resveratrol nanostructured lipid carrier (NLC). Pembawa lipid berstrukturnano (NLC) dibuat dengan teknik homogen geser tinggi. Untuk menentukan karakterisasi NLC, digunakan kalorimetri pemindaian difraksi, difraksi sinar-X, dan spektrofotometri inframerah Transformasi Fourier. Pemeriksaan bentuk morfologis dilakukan dengan mikroskop elektron transmisi. Ukuran partikel dan pemeriksaan indeks polidispersitas diukur dengan penganalisa ukuran partikel Delsa Nano Tм, sedangkan efisiensi menjebak resveratrol dalam sistem NLC diukur dengan metode membran dialisis. Selanjutnya, uji kedalaman penetrasi pada kulit tikus dilakukan dengan metode mikroskop fluoresensi menggunakan penanda rhodamin B. Uji stabilitas fisik dilakukan dengan memeriksa ukuran partikel dan indeks polidisitas selama 30 hari. Formula dengan minyak kacang kedelai cair dan lipid cair asam oleat meningkatkan karakteristik termasuk efektivitas jebakan dan stabilitas koloid. Namun, formula dengan minyak kacang kedelai dan cairan kombinasi asam oleat tidak memberikan penetrasi yang lebih baik ke dalam kulit daripada penggunaan lipid cair tunggal. Sedangkan formula dengan minyak kacang kedelai dan lipid cair asam oleat terbukti meningkatkan stabilitas fisik selama 30 hari.

Kata kunci: Pembawa lipid berstrukturnano; resveratrol; minyak kacang kedelai; asam oleat; cetyl palmitat; homogenisasi tekanan tinggi; sifat fisikokimia; penetrasi kulit

Correspondence: Widji Soeratri, Department of Pharmaceutical, Faculty of Pharmacy, Universitas Airlangga, Dharmawangsa Dalam, Surabaya, Indonesia. E-mail: widjisoeratri@yahoo.com

pISSN:2355-8393 • eISSN: 2599-056x • doi: http://dx.doi.org/10.20473/fmi.v55i3.15505

- Fol Med Indones. 2019;55:213-222 • Received 10 May 2019 • Accepted 24 Aug 2019

- Open access under CC-BY-NC-SA license • Available at https://e-journal.unair.ac.id/FMI/

\section{INTRODUCTION}

Resveratrol (trans-3,5,4'trihydroxystilbene) is an antioxidant found in seeds, red grape skin, peanuts, blueberries, and several other fruits. One resveratrol consists of two forms of cis isomeric structures and trans-resveratrol. The form of cis isomers and transresveratrol is natural forms that have different biological and pharmacological effects (Kim et al 2012), but the trans form is more dominant and stable than the cis 
(Chen et al 2007, Amri et al 2012). Resveratrol as an antioxidant shows several benefits for human health, including preventing cardiovascular disease, anticancer, and anti-aging for skin (Sun et al 2014). Resveratrol as an anti-aging for skin works through two mechanisms, which are by reducing the activation of protein 1 (AP-1) and nuclear factor kappa beta (NF-kB) which play an important role in the pathogenesis of skin aging.

AP-1 is responsible for the synthesis of metalloproteinases (MMPs). Moreover, MMP is responsible for the degradation of collagen while NF-kB plays a role in the activation of various inflammatory mediators (Farris 2014). Resveratrol as an antioxidant has several disadvantages namely low solubility to water and an unstable material for light (Neves et al 2013, Zupancic et al 2014). Due to that, a topical delivery system is needed so that it can maintain the stability of active ingredients.

Topical delivery system with lipid-based carriers that can improve the stability of active ingredients is nanostructured lipid carriers (NLC). NLC is the second generation of lipid nanoparticles developed to overcome the disadvantages of solid lipid nanoparticles (SLN). NLC is more effective in increasing entrapment effectiveness and drug release prevention in the system during the storage period (Pezeshki et al 2014). In addition, to overcome the disadvantages of SLN, NLC can also increase penetration and the stability of active ingredients during the storage period ( $\mathrm{Li} \& \mathrm{Ge} 2012$ ). Nanostructured lipid carriers (NLC) are made using a mixture of solid lipids and certain liquid lipids (Pardeike et al 2009). The presence of liquid lipids can reduce crystal lattice regularity so that it can create a larger room for accommodation of active ingredients, thereby improving the effectiveness of entrapment.

In the previous study, NLC with the all trans retinoid (ATRA) drug with cetyl palmitate solid lipids and combination of liquid lipids (soy bean oil and oleic acid) with a ratio (4:3:1) was able to increase trapping capacity of NLC with ATRA physicochemical stability compared with a single liquid lipid by comparison (4:4:0) (Chinsriwongkul et al 2011). Conversely, in this study, NLC RSV is made with a ratio of 4:4:0, 4:0:4 and $4: 2: 2$ and this study intends to analyze the effect of the combination of liquid lipids (soy bean oil and oleic acid) on the characteristics, penetration, and physical stability of resveratrol NLC.

\section{MATERIALS AND METHODS}

The ingredients used in this study have pharmaceutical grade purity. The main ingredients used in this study are resveratrol from Naturalin Bio Resources (China), cetyl palmitate (BASF, Germany), soybean oil (Natures, India) and oleic acid (Brataco Ltd., Indonesia), Propilenglycol (Dow Chemical Pacific, Singapore), Polysorbate-80 (Kao Corporation, Tokyo), Ethanol pa (Merck, Germany), and Acetat buffer pH $5.0 \pm 0.05$.

\section{Preparation of resveratrol NLC}

The NLC system was made using the High Shear Homogenization (HPH) method (Gerszon et al 2014). Resveratrol is dissolved in liquid lipids (soy bean oil and oleic acid) and mixed solid lipids (cetyl palmitate), then at the same time hot surfactants were added (temperature at fused lipids) then sterilizered at 5000 rpm for 3 minutes. The next step was propilenglycol and acetat buffer pH 5 ad $100 \mathrm{ml}$, emulsion mixture o/w were homogenized at $16.000 \mathrm{rpm}$ (Ultra Turrax T-25 IKA Labortechnik) for 3 minutes and 5 cycles. The last stage of the emulsion was distilled at a speed of 500 rpm at room temperature until it was cool and the NLC system was formed.

\section{Physical and chemical characterization}

Infrared spectroscopy

Infrared spectra were examined by Fourier transform infrared spectrometer (Jasco 4200, Germany). Resveratrol, soy bean oil, oleic acid, and RSLC NLC were prepared. The samples were dispersed with a ratio of $(1: 1)$, Kbr powder was dried and then pressed with a hydraulic press equipped with a steam vaporizer to obtain a translucent plate. The plates were scanned at a wavelength of $400-4000 \mathrm{~cm}$.

\section{Differential scanning calorimetry}

Differential scanning calorimetry (DSC) was analyzed using DSC-60Plus. Measurement of DSC (3-5 mg powder sample) included in the $40 \mu \mathrm{l}$ of crucible was carried out at the temperature of $5^{\circ} \mathrm{C}-300^{\circ} \mathrm{C}$ with an increase in the temperature of $10^{\circ} \mathrm{C} /$ minute (Anant et al 2003).

\section{X-ray diffraction (XRD)}

The sample was analyzed using a Philips X'Pert X-ray diffractometer, and inserted in the pan holder. Then it was measured with a condition of $40 \mathrm{kV}$ of voltage; 30 $\mathrm{mA}$; and scanned at an angle of $2 \theta$ angle from $5^{\circ}$ to $50^{\circ}$ with the speed of $5 \% \mathrm{~min}$.

\section{Efficiency of entrapment}

Measurement of entrapment efficiency was done using a membrane filter with molecular weight cut-off 12000 
$\mathrm{kDa}-14000 \mathrm{kDa}$. Lipid nanoparticles were inserted into the membrane filter and centrifuged at $500 \mathrm{rpm}$ for 7 hours. The supernatant obtained was filtered using whatman membrane filter with a diameter of $0.2 \mu \mathrm{m}$, then the amount of active ingredients trapped in the NLC was calculated with the formula:

$$
\mathrm{EE}(\%)=\frac{\mathrm{Wi}-\mathrm{Wf}}{\mathrm{Wi}} \times 100 \% \text { Information }
$$

In which Wi: Number of active ingredients and Wf: The amount of active ingredients in the supernatant (active ingredients which were not trapped in the NLC system).

Then calculated the average and the standard deviation price of the entrapment of resveratrol in the Nanostructured Lipid Carrier (NLC) system (Gokce et al 2012).

Particle size and Particle size distribution (Polidispersity index)

An examination of the diameter of the particle size and polydispersity index (PDI) of the resveratrol NLC system was carried out with DelsaTM Nano Sub Micron Particle Size Analyzer. The NLC was dispersed with distilled water (1:40) and then inserted into the cuvette. The next filled cuvette sample was inserted into the sample holder. The particle size analyzer would measure the sample for 10 minutes. The Polydispersity Index (PI) described variations in the sample. A PDI value of less than 0.3 indicated that the sample was mono dispersion.

\section{Viscosity test}

Viscosity of the Nanostructured Lipid Carrier (NLC) system was an evaluation to observe the influence of the addition of other materials such as surfactants and the effects of manufacturing technique. The viscosity test was performed using a Rion viscosity meter, using the rotor no 2. 100-4000 dps and a glass sample container of $400-500 \mathrm{ml}$. The NLC $150 \mathrm{gr}$ was inserted in the container, attached the rotor to the container to make sure it was closed to the bubble, and spread evenly on the surface of the rotor. Then the viscosity meter was turned on and then left for a while until the reading was stable.

\section{Measurement of Zeta potential}

Zeta potential measurement was needed to be done because zeta potential value provided information of the stability of a colloid during storage. Zeta potential showed the charge of colloidal particles which was associated with electrostatic repulsion between particles, preventing aggregation of colloidal particles. Potential zeta measurements use Zetasizer Nano ZS (Malvern, UK). NLC was dispersed with distilled water (1:40) and then inserted into the cuvette. The sample cuvette was entered into the Zetasizer Nano ZS sample holder. A colloid was declared stable at storage if its potential zeta value was higher than $+30 \mathrm{mV}$ or lower than $-30 \mathrm{mV}$ (Loo et al 2013).

\section{Transmission of electron microscopys}

Droplet morphology was seen by using Transmission Electron Microscopy (TEM). This check was done to determine the particle shape of the NLC system. Three drops of sample were placed in a carbon coated copper lattice that had been dried at room temperature, then observed at a voltage of $120 \mathrm{KVA}$.

$$
\mathrm{EE}(\%)=\frac{\mathrm{Wi}-\mathrm{Wf}}{\mathrm{Wi}} \times 100 \% \text { Information }
$$

In which Wi: Number of active ingredients and Wf: Number of active ingredients in supernatant (nonentrapment active ingredients in NLC system).

Next, the average and the standard deviation of the efficiency of entrapment of resveratrol in the Nanostructured Lipid Carrier (NLC) system were calculated (Gokce et al 2012).

Invivo penetration analysis

In the initial stage, mice were anesthetized by giving ketamine $20 \mathrm{mg} / \mathrm{kg}$ of the body weight until the mice were unconscious ( \pm 45 minutes), then placed them on the board with the position of the legs plastered. Then, the hair of the mouse was shaved on the back carefully so as not to wound, then the skin area of the mice was divided by hypafix with an area of $\pm 2 \times 3 \mathrm{~cm}^{2}$, then the test sample was applied to the area that had been divided. Waited for 2 hours then the mice were exterminated with a dislocation. The same steps were carried out periodically at the 4th and 6th hours. The part of the skin that had been applied to the sample was cut using dermastomisation. After that, the skin tissue was washed three times with absolute alcohol. Embedding was done by means of the sample planted in liquid paraffin on the inert paper beam. The object was placed in accordance with the cutting orientation, left until it froze and then stored in the block holder. Samples were cut transversally and horizontally using a cryotome (Tissue-Tek Cryo3, Sakura) at $-59^{\circ} \mathrm{C}$ with a size of $1 \mathrm{~mm} 2$ and thickness of $5 \mu \mathrm{m}$. The final stage of the Slices was visualized using a fluorescence microscope (Olympus FX-100) with 42x magnification. In addition penetration depth was analyzed and fluorine 
intensity of rhodamine B markers on each skin layer was observed.

Physical stability test

Stability test of resveratrol Nanostructured Lipid Carriers (NLC) system was carried out after storaged in the refrigerator at the temperature of $8-15^{\circ} \mathrm{C}$ and protected from direct sunlight exposure. Resveratrol stored Nanostructured Lipid Carrier (NLC), then reevaluated physical characteristics for 30 days which included particle size and polydispersity index. The results obtained were compared with the initial preparation characterization (Hu et al 2005).

\section{Statistical analysis}

Statistical analysis for the evaluation of characteristics (viscosity, particle size, zeta potential value (\% EE), and physical stability test) was using one way variance analysis (ANOVA) method. If significant values were obtained $<0.05$, then this indicated a significant difference. To find out which NLC formula was different, the analysis was continued with multiple comparison tests using Post Hoc Multiple Comparison.

\section{RESULTS AND DISCUSSION}

\section{Preparation of NLC RSV}

In previous studies, it was reported that NLC ATRA contained 30\% lipids, with solid and liquid lipids ratio 1:1 could increase entrapment capacity and physical stability. Therefore, in this study selected ratio of solid liquid lipids ratio was $1: 1$. Furthermore, in this study the formulas were made by comparing single liquid lipids and liquid lipids combined with the ratio of cetyl palmitate (CP): soybean oil (SO): oleic acid (OA), CP/SO (4:4:0), CP/OA (4:0:4) and CP/SO/OA (4:2:2).
Then, character checking, penetration, and stability were carried out.

\section{Infrared spectra}

Examination with FTIR aimed to observe the appearance or loss of functional groups that occured in the resveratrol NLC system that was formed. Based on the results of FTIR examination (Fig. 1), resveratrol F1, F2 and F3-NLC formulas had FTIR spectrum profiles that were identical to resveratrol. This indicated that resveratrol was dispersed in the lipid matrix and there was no chemical interaction between resveratrol and the lipid matrix (Sun et al 2014).

\section{Differential scanning calorimetry}

Based on the overlay results on the NLC RSV thermogram with cetyl palmitate solid lipids (Fig. 2), it showed that there were 2 endothermic peaks on the RSV NLC system. The first peak (Table 2), with a melting point between $46.33^{\circ} \mathrm{C}-48.94^{\circ} \mathrm{C}$, was lower than the melting point of cetyl palmitate. This was related to the a-polymorphic form (thermodynamic instability). The a-polymorphic form was a less order form, this form indicated liquid lipids melting with cetyl palmitate and decreased the density of the crystal structure of cetyl palmitate while the second peak had a melting point of $117.05^{\circ} \mathrm{C}-136.66^{\circ} \mathrm{C}$, which showed a higher melting point than the melting point of Cetyl palmitate. This was related to the $\beta$-polymorphic form (thermodynamic stability). The B-polymorphic form indicated modification of the crystal structure of cetyl palmitate into a more ordered crystalline form. The two forms of polymorphism were probably due to the high concentration of tween 80, thus inducing crystallization. (Girdthep et al 2011). On RSV NLC examination with bulk resveratrol seen, the NLC RSV endothermic peak of all formulas was lower than bulk resveratrol $267.57^{\circ} \mathrm{C}$ thus indicating that resveratrol dissolved in lipid matrixs (Rosa 2011).

Table 1. The Composition of Resveratrol loaded nanostructured lipid carriers

\begin{tabular}{lccc}
\hline & \multicolumn{3}{c}{ NLC Formula } \\
\cline { 2 - 4 } Composition (\%b/b) & $\begin{array}{c}\text { F1-RSV } \\
\text { CP/SO }\end{array}$ & $\begin{array}{c}\text { F2- RSV } \\
\text { CP/OA }\end{array}$ & F3-RSV \\
& 1 & 1 & 1 \\
Resveratrol & 15 & 15 & 15 \\
Cetyl palmitat (CP) & 15 & - & 7.5 \\
Soy bean oil (SO) & - & 15 & 7.5 \\
Oleic Acid (OA) & 20 & 20 & 20 \\
Tween 80 & 20 & 20 & 20 \\
Propilenglycol & 100 & 100 & 100 \\
Acetate buffer pH 5 & & & \\
\hline
\end{tabular}




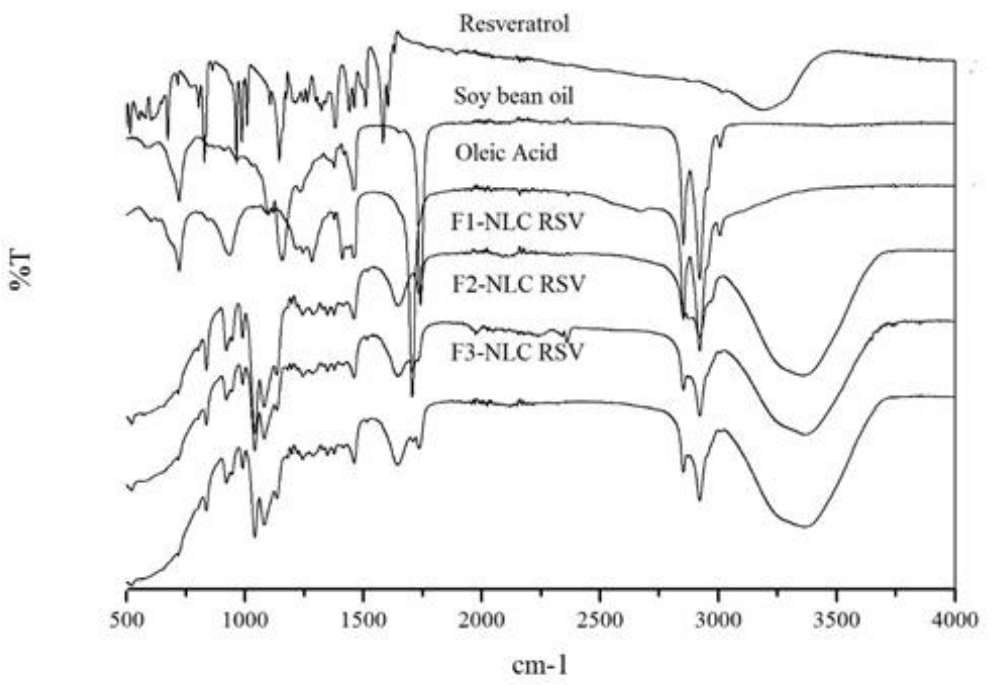

Fig. 1. Infrared Spectra from Resveratrol, Soy Bean Oil, Oleic Acid, and NLC RSV- F1, F2, and F3.

Table 2. Blank NLC and RSV Thermogram

\begin{tabular}{lcccccc}
\hline \multirow{2}{*}{ NLC Formula } & \multicolumn{3}{c}{ Peak 1 } & \multicolumn{3}{c}{ Peak 1 } \\
\cline { 2 - 7 } & Peak & $\begin{array}{c}\text { Enthalpy } \\
(\mathrm{j} / \mathrm{g})\end{array}$ & $\begin{array}{c}\text { RI } \\
(\%)\end{array}$ & Peak & $\begin{array}{c}\text { Enthalpy } \\
(\mathrm{j} / \mathrm{g})\end{array}$ & $\begin{array}{c}\text { RI } \\
(\%)\end{array}$ \\
\hline F1- RSV CP/SO & 46.65 & -14.48 & 6 & 136.66 & -223.19 & 96 \\
F2- RSV CP/OA & 46.33 & -14.08 & 6 & 117.05 & -259.71 & 111 \\
F3- RSV CP/SO/OA & 48.94 & -17.78 & 8 & 120.95 & -249.35 & 107 \\
Cetyl palmitate & 51.17 & -232.85 & 100 & & & \\
Resveratrol & 267.57 & -87.84 & - & & & \\
\hline
\end{tabular}

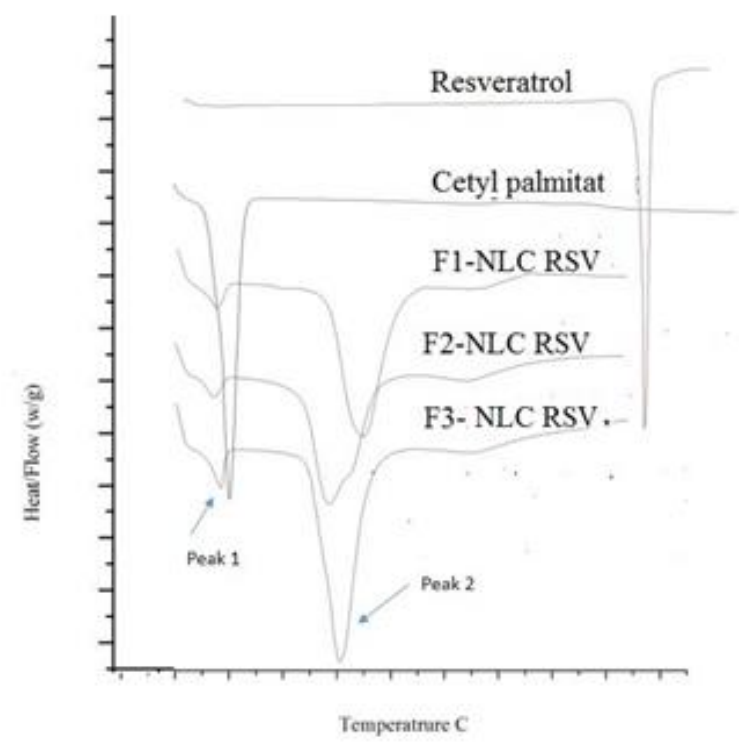

Fig. 2. Thermogram results of resveratrol, cetyl palmitat, NLC F1 (CP/SO), F2 (CP/OA), and F3 CP/SO/OA. 


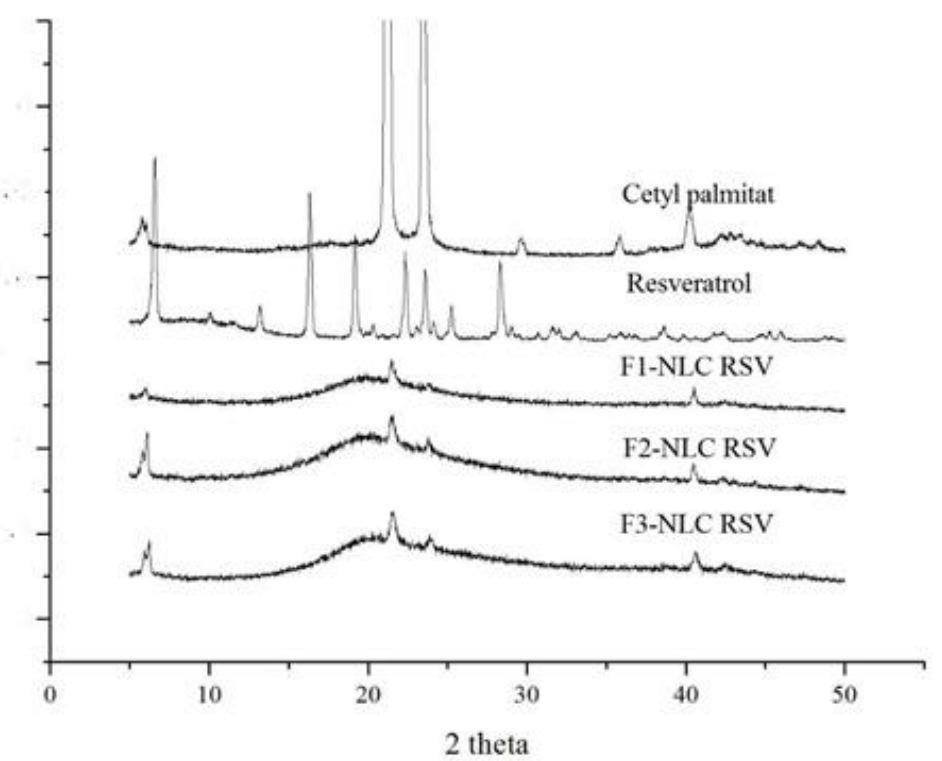

Fig. 3. Diffractogram results of resveratrol, cetyl palmitat, NLC F1 (CP/SO), F2 (CP/OA), and F3 CP/SO/OA.

\section{X-ray diffraction (XRD)}

On XRD examination (Fig. 3), bulk Cetyl palmitate had a sharp diffraction peak at an angle of $5^{\circ}, 6^{\circ}, 21^{\circ}, 23^{\circ}$, $40^{\circ}$ which indicated that cetyl palmitate was in crystal form. After the addition of liquid lipid soy ben oil and oleic acid made in the NLC system, there was a decrease in peak intensity with characteristics similar to bulk Cetyl palmitate, but with a weaker intensity. If the results of the diffractogram were associated with DSC data it could be concluded that the addition of liquid lipids decreased the structure of cetyl palmitate crystals characterized by declining of (\%) RI (Chinsriwongkul et al 2011). Furthermore, on examination of resveratrol, sharp diffraction peaks at angles $6^{\circ}, 16^{\circ}, 19^{\circ}, 22^{\circ}$, and $28^{\circ}$. After being made in the form of NLC, the peak characteristic of resveratrol for all RSV NLC formulas was not shown in the diffractogram. This showed that resveratrol was dispersed into an amorphous form in the lipid matrix (Chinsriwongkul et al 2011).

\section{Entrapment efficiency}

Based on the results of the Analysis of Variance (Anova) statistics on trapping efficiency checks, the value of $\mathrm{p}$ value ( $\mathrm{sig}$ ) was smaller than 0.05 . This showed a significant difference, in which the F2 formula with oleic acid liquid lipids showed the lowest EE $(91.78 \pm 0.05)$ compared to F1 formula with soy bean oil liquid lipids $(95.28 \pm 0.09)$ and F3 liquid lipids oleic acid + soy bean oil $(95.17 \pm 0.08)$. This could be caused by the lower solubility of resveratrol in oleic acid $(0.07 \mathrm{mg} / \mathrm{g})$ compared to soybean oil $(2 \mathrm{mg} / \mathrm{g})$, resulting in lower entrapment in formulas with high oleic acid liquid lipids. The percentage $(\%)$ of RI in the F2 formula also affected the reduction in space to accommodate more drugs, resulting in lower entrapment. However, the presence of the combination of liquid lipids in the F3 formula was able to increase the entrapment effectiveness of $95.17 \pm 0.08$ so that it could be concluded that the combination of liquid lipids had an effect on increasing entrapment efficiency.

\section{Particle size and particle size distribution (polydispersity index)}

Based on the statistical results of the Analysis of Variance (Anova) of RSV NLC, the value of $p$ value (sig) was smaller than 0.05. This showed that there was a significant difference, where the F1-NLC RSV formula had a smaller particle size of $338.56 \pm 48.53$ compared to the RSV F2-NLC formula $(529.90 \pm 45.08)$ and F3-NLC RSV (518, $00 \pm 45.72)$. F1-NLC RSV formula with soy bean oil liquid lipids yielded smaller particle size. This was related to the high solubility of resveratrol in soy bean oil so that it affected the small particle size (Liang et al 2008). On the examination results of particle size distribution (table 2) for all formulas, the results showed no significant difference, in which the PDI value was less than 0.3 , so it could be concluded that the RSV NLC polidispersity index (PDI) was uniform. 
Table 3. The size of particle, polydispersity index, and entrapment efficiency of NLC RSV with different liquid lipid $($ mean $\pm \mathrm{SD}, \mathrm{n}=3$ ).

\begin{tabular}{lllc|}
\hline NLC Formula & Z-average $(\mathrm{nm})$ & PDI & EE $(\%)$ \\
\hline F1- RSV CP/SO & $338.56 \pm 48.53$ & $0.235 \pm 0.01$ & 95.28 \\
F2- RSV CP/OA & $529.90 \pm 45.08$ & $0.262 \pm 0.09$ & 91.78 \\
F3- RSV CP/SO/OA & $518.00 \pm 45.72$ & $0.241 \pm 0.02$ & 95.17 \\
\hline
\end{tabular}

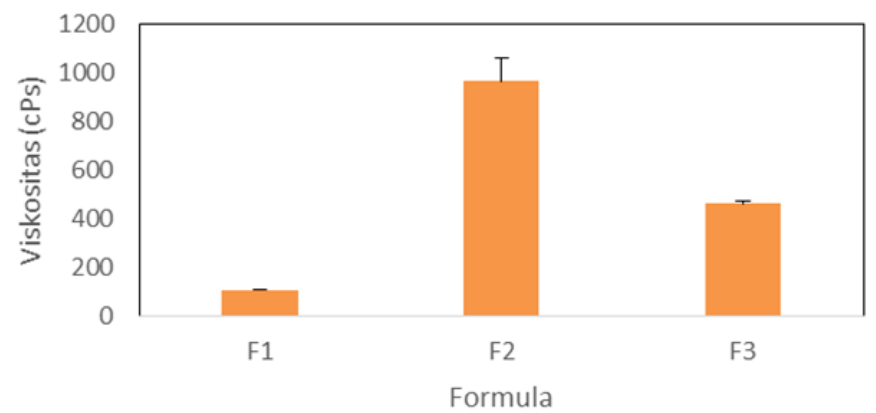

Fig. 4. Viscosity results of NLC RSV F1 (CP/SO), F2 (CP/OA), and F3 CP/SO/OA.

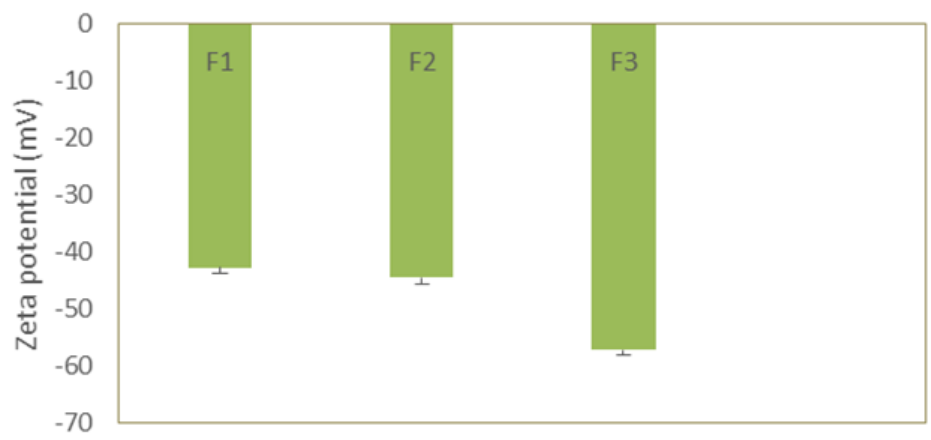

Fig. 5. Zeta potential results of NLC RSV F1 (CP/SO), F2 (CP/OA), and F3 CP/SO/OA.

\section{Viscosity of the NLC}

On the viscosity examination (in figure 5), the RSV F2 NLC obtained was $(966.60 \pm 94.28)$. It was greater than F1 RSV NLC (106.67 \pm 4.71$)$ and F3 (463.30 \pm 12.4$)$. This was directly proportional to the results of the storage stability test for 30 days that showed the formula $\mathrm{F} 2$ produced a stable formula, as stated 18 that if the viscosity was greater, the stability would increase.

\section{Zeta potential}

On the zeta potential examination (figure 4), all NLC formulas showed negative values above $-30 \mathrm{mV}$, so that all formulas were declared stable. Based on the results of Analysis of Variance (ANOVA), the value of p value (sig) was smaller than 0.05 . This showed that there was a significant difference, where the F3 formula $(-57.2 \pm$ 0.65 ) had a higher zeta potential value compared to the F1 formula $(-42.7 \pm 2.45)$ and F2 $(-44.5 \pm 2)$ (Sinko 2011). The F3 formula with the liquid combination of soy bean oil and oleic acid was an unsaturated fatty acid that had a similar carbon chain double bond, and if combined it would produce a high level of repulsion rejection between charged particles, and preventing flocculation. This was in accordance with the DLVO theory (Derjaguin-Landau-Verwey-Overbeek theory) which stated that the system could be said to be stable if electrostatic repulsion dominated the van der wall force (Spitzer 2003). 

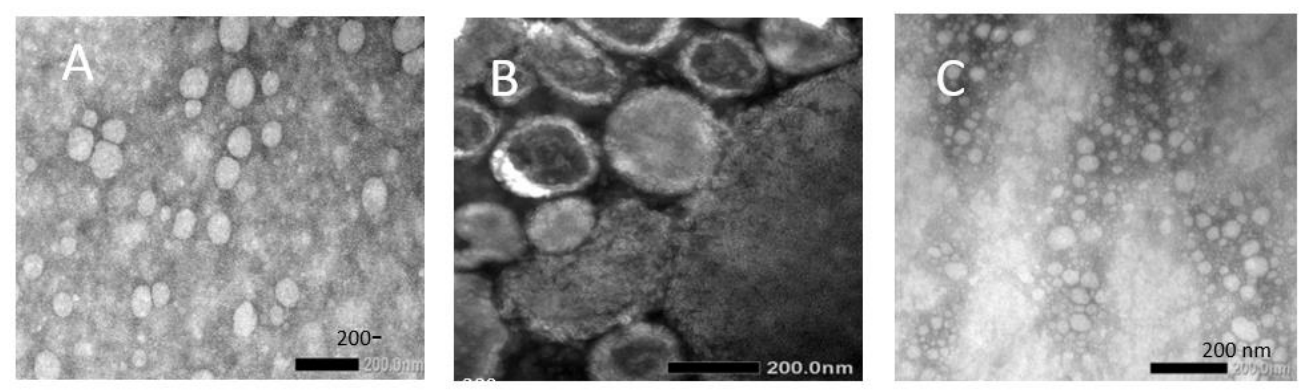

Fig. 6 . TEM results of A. NLC RSV F1(CP/SO), B. NLC RSV F2 (CP/OA), and C. NLC RSV F3 (CP/SO/OA).

Table 4. Invivo penetration test results on mice's back skin on the 2nd, 4th, and 6th hours

\begin{tabular}{lll}
\hline NLC Formula & \multicolumn{1}{c}{$\begin{array}{c}\text { Average of Penetration Depth } \\
(\mu \mathrm{m}) \pm \text { SD }\end{array}$} \\
\hline F1- RSV CP/SO & 2 hours & $112.65 \pm 8.07$ \\
& 4 hours & $497.27 \pm 77.88$ \\
\hline F2-RSV CP/OA & 6 hours & $651.77 \pm 78.23$ \\
\hline F3-RSV CP/SO/OA & 2 hours & $85.53 \pm 8.31$ \\
& 4 hours & $270.87 \pm 20.89$ \\
& 6 hours & $498.50 \pm 33.92$ \\
\hline
\end{tabular}

\section{Transmission Electron Microscopy (TEM)}

On particle morphology examination using transmission electron microscopy (TEM), each formula showed the shape of spherical particles. The spherical form had a greater solubility in the water phase, so it could increase the biovaibility of medicinal ingredients with low solubility (Chatterjee et al 2014).

\section{In vivo penetration}

From the results of the in vivo penetration test, the result of the F1 RSLC NLC could penetrate deeper than the result of the F2 RSV NLC formula and F3 RSV NLC. This was because the NLC RSV F1 had a small particle size. Small particle size caused the structure between the particles became tight so that the occlusivity increased, in which also increased occlusivity that affected the penetration of active ingredients into the skin (Putranti et al 2017). In addition, the solubility of active ingredients in lipids also affected penetration, evidenced with how soy bean oil liquid lipids were more soluble in resveratrol than in F1 formula. Moreover, the solubility of lipids in the active ingredient could affect the diffusion coefficient between the drug and the skin membrane so that active ingredients were able to penetrate better (Junyapraset \& Supaporn 2008).

\section{Physical stability}

The last stage of the physical stability test of the NLC system was testing resveratrol for 30 days. In this test, particle size and particle size distribution were examined. Particle size and particle size distribution were chosen as stability parameters of nanoparticles because they played an important role in evaluating colloidal form during storage. From the results of the measurement of size stability and size distribution (PDI), the results of RSV F2 and F3 NLC formulas were more stable than the F1 RSV NLC formula. The size instability of the F1 formula with soy bean oil liquid lipids was related to the XRD data, where the F1 formula was more amorphous than the other formulas. The high amorphous form tended to be unstable and changeed to the crystalline form over time which affected the particle size stability (Wu et al 2011). In addition, the viscosity of F1 formula was lower than that of formula F2 and F3, in which low viscosity had an effect on decreasing stability (Raymundo et al 2001). In addition, according to the sedimentation theory, Stokes's law states that the value of viscosity is inversely proportional to sedimentation speed (Sinko 2011). Lower viscosity would be easier for agglomeration to occur. In the particle size distribution (PDI) stability test, the F1 NLC size distribution was found to be unstable compared to NLC F2 and F3. 

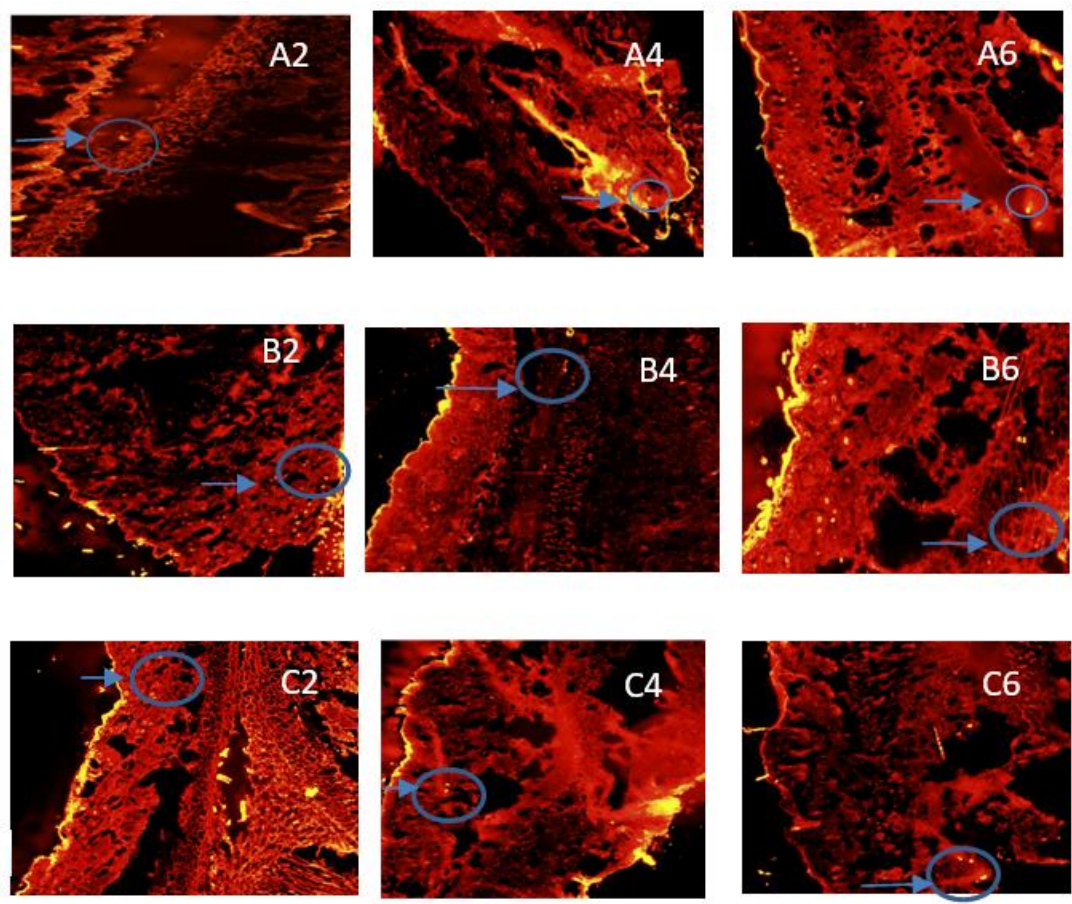

Fig. 7. Penetration test result on the 2nd, 4th, and 6th hours of A. NLC RSV F1(CP/SO), B. NLC RSV F2 (CP/OA), and C. NLC RSV F3 ( CP/SO/OA).

Fig. 8. Physical stability test result of particle for 30 days of NLC RSV F1(CP/SO), NLC RSV F2 (CP/OA), and NLC RSV F3 (CP/SO/OA).

Chart Title
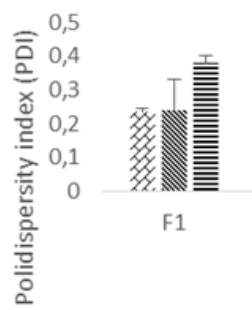

F1

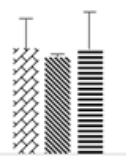

F2

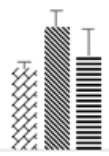

F3

Formula NLC RSV

«day 1 \&day $14 \equiv$ day 30

Fig. 9. Polydispersity index physical stability test result for 30 days of NLC RSV F1(CP/SO), NLC RSV F2 (CP/OA), and NLC RSV F3 (CP/SO/O).

\section{CONCLUSION}

Resveratrol made in the NLC system has been successfully made with the modification of the High Shear Homogeniza technique. Different matrix lipids are developed to improve character and increase penetration and physical stability of resveratrol on the skin. Formulas with liquid soy bean oil and oleic acid liquid lipids made in the NLC system are able to improve character (including entrapment efficiency and colloidal stability) and are able to increase physical stability of NLC resveratrol for 30 days. On the other 
hand, the penetration evaluation formula with soy bean oil and oleic acid combination liquid lipids does not provide better penetration than single liquid lipids.

\section{REFERENCES}

Amri A, Chaunnel JC, Charruan C (2012). Administration of resveratrol: what formulation solutions to bioavaibility limitations. Journal of controlled release, 182-193

Chatterjee P, Bagchi S, Sengupta (2014). The uniform early structural response of globural proteins to cold denaturing conditions:a case study. J Chem Phys., 141

Chen X, He H, Wang G, Yang B, Ren W, Ma L, Yu (2007). Stereospecific determination of cis- and transresveratrol in rat plasma by HPLC: application to pharmacokinetic studies. Biomedical Chromatography 21, 257-265

Chinsriwongkul A, Ponwanit C, Tanasait N, Theerasak R, Warisada Sila-on., Ruktanonchai, Praneet O (2011). Nanostructured Lipid Carriers (NLC) for parenteral delivery of an anticancer drug. American Association of Pharmaceutical Sciences 13, 150-158

Farris PK (2014). Cosmeceuticals and cosmetic practice. USA, John Wiley \& Sons Ltd, p 165-172

Gerszon J, Aleksandra R, Mieczyslaw P (2014). Antioxidant properties of resveratrol and its protective effects in neurodegenerative diseases, 97-117

Gokce, Emrah K, Eleonora D, Giuseppina S, Bonferoni MC, OzgenO (2012). Resveratrol-loaded solid lipid nanoparticles versus nanostructured lipid carriers: evaluation of antioxidant potential for dermal applications. International Journal of Nanomedicine 7, $1841-1850$

Hu F, Qiang, Sai-P J, Yong-Z D, Hong Y, Yi-Qing Y, $\mathrm{Su} \mathrm{Z}$ (2005). Preparation and characterization of stearic acid nanostructured lipid carriers by solvent diffusion method in an aqueous system colloids and surfaces B. Biointerfaces 45, 167-173

Junyapraset V, Supaporn P (2008). Floating properties and release characteristic of hollow microspheres of acyclovir. Drug Delivery 15, 331-341

Kim S, Wai KN, Yuangcai D, Surajit D, Reginald T (2012). Preparation and physochemical characterization of trans-resveratrol nanoparticle by temperature-controlled antisolvent precipitation. Journal of Food Enggineering 108, 37-42

Li B, Ge ZQ (2012). Nanostructured lipid carriers improve skin permeation and chemical stability of idebenone. American Association of Pharmaceutical Sciences, 276-283
Liang L, Tajmir-Riahi HA, Muriel S (2008). Interaction of $\mathrm{b}$ lactoglobulin with resveratrol and its biological implications. Biomacromolecules 9, 50-56

Loo CH, Basri M, Ismail R, Lau HLN, Tejo BA, Kanthimathi MS, Hassan HA, Choo YM (2013). Effect of compositions in nanostructured lipid carriers (NLC) on skin hydration and occlusion. International Journal of Nanomedicine 8, 13-22

Neves AR, Marlene L, Susana M, José LC, Salette R (2013). Resveratrol nanodelivery systems based on lipid nanoparticles to enhance its oral bioavailability. International Journal of Nanomedicine 8, 177-187

Pardeike J, Aiman H, Rainer H, Muller (2009). Lipid nanoparticle (LN, NLC) in Cosmetic and Pharmacheutical. International Journal Of Pharmacceutics 366, 170-184

Pezeshki A, Ghanbarzadeh B, Mohammadi M, Isa F, Hamed H (2014). Encapsulation of vitamin A palmitate in Nanostructured Lipid Carrier (NLC)effect of surfactant concentration on the formulation propertie. Advances Pharmaceutical Bulletin 4, 563568

Putranti AR, Riesta P, Esti H (2017). Effectivity and physicochemical stability of nanostructured lipid carrier coenzyme q10 in different ratio of lipid cetyl palmitate and alpha tocopheryl acetate as carrier. Asian J Pharm Clin Res 10, 147-151

Raymundo A, Franco JM, Empi J, Sousa I (2001). Optimazation of the composition low fat oil in water emulsion stabilized by with protein. Journal American oil Chemist 79, 783-790

Rosa NAB (2011). Development of nanoparticles loaded with bioactive compounds for application as nutraceuticals. A dissertation. Engineering of Oporto University, p 60-69

Sinko P (2011). Physical pharmacy and pharmaceutical science. 6th Ed. China, Lippincont William and Wilkins, p 355-367, 469-473

Spitzer JJ (2003). Colloidal interactions: contact limiting laws, double-layer dissociation and nonDLVO. Colloidal and Polymer Scieence, 589-592

Sun RG, Zhao S, Ni Q, Xia (2014). Lipid based nanocarriers with different lipid compositions for topical delivery of resveratrol: Comparative analysis of characteristics and performance. Journal of Drug Delivery Science and Technology 24, 591-600

Wu L, Zhang J, Watanabe (2011). Physical and chemichal stability of drug nanoparticle. Adv Drug Delivery, 456-69

Zupancic, Špela ZL, Julijana K (2014). Stability and solubility of trans-resveratrol are strongly influence by $\mathrm{pH}$ and temperature. European Journal of Pharmaceutics and Biopharmaceutics, p 1-29 